\title{
Synthesis and Antitumor Activity of Novel Thienopyrimidine Derivatives Containing Thiosemicarbazide Moiety
}

\author{
Samir B. Salib, Omneya M. Khalil, Mona M. Kamel, Yara El-Dash* \\ Pharmaceutical Organic Chemistry Department, Faculty of Pharmacy, Cairo University, Cairo, Egypt \\ Email: 'yara_eldash@hotmail.com, ”yara.el-dash@pharma.cu.edu.eg
}

Received 5 July 2016; accepted 23 July 2016; published 26 July 2016

Copyright (C) 2016 by authors and OALib.

This work is licensed under the Creative Commons Attribution International License (CC BY). http://creativecommons.org/licenses/by/4.0/

(C) (†) Open Access

\section{Abstract}

The present study focused on synthesizing a series of novel derivatives of 4-aryl-1-[2-(3-benzyl-4oxo(3H)-5,6,7,8-tetrahydro[1] benzothieno[2,3-d]pyrimidin-2-ylsulphanyl) acetyl] thiosemicarbazide 5a-d and evaluating their antitumor activity. The structure of the synthesized compounds has been elucidated on the basis of elemental analyses and spectroscopic methods (IR, ${ }^{1} \mathrm{H}-\mathrm{NMR}$, ${ }^{13} \mathrm{C}-\mathrm{NMR}$ and MS). The in vitro cytotoxic activity of the synthesized derivatives was evaluated against two human cell lines: prostate cancer (PC-3) and colon cancer (HCT-116).

\section{Keywords}

Synthesis, Thieno[2,3-d]Pyrimidine, Thiosemicarbazides, Anticancer Agents

\section{Subject Areas: Medicinal Chemistry, Organic Chemistry}

\section{Introduction}

In the last few years, cancer attracted great attention and noticeable progress has been made in the discovery and development of modern anticancer drugs. However, despite advances that have led to the development of new therapies, cancer continues to be a major health problem worldwide due to various factors [1]-[3]. Therefore, discovering newer and safer anticancer agents continues to be a challenge [4].

In the course of finding novel chemical agents that may serve as innovative antitumor agents, quinazoline derivatives are of particular interest [5]. In the last few years, the thieno[2,3-d]pyrimidine core was evaluated as bioisostere of 4-anilinoquinazoline core which included potent marketed anticancer drugs like Gefitinib (Ires$\mathrm{sa}^{\mathrm{TM}}$ ) [6], Erlotinib (Tarceva ${ }^{\mathrm{TM}}$ ) [7] and Tandutinib (MLN518) (phase II clinical trials) [8]. Recently, large number of thieno[2,3- $d]$ pyrimidine derivatives were found to be active against different cancer types exerting

\footnotetext{
${ }^{*}$ Corresponding author.
}

How to cite this paper: Salib, S.B., Khalil, O.M., Kamel, M.M. and El-Dash, Y. (2016) Synthesis and Antitumor Activity of Novel Thienopyrimidine Derivatives Containing Thiosemicarbazide Moiety. Open Access Library Journal, 3: e2876. 
their antitumor activities via different mechanisms [9]-[13]. Consequently, the thieno[2,3-d]pyrimidine ring system constitutes an attractive target for the design of new anticancer drugs through wide structure variations.

On the other hand, thiosemicarbazide derivatives exhibit significant biological activities, ranging from antitumor, fungicidal, bactericidal, anti-inflammatory and antiviral activities [14]-[16]; therefore, the thiosemicarbazide is a highly efficient pharmacophore in drug molecular design. In the present work, novel thieno[2,3- $d$ ] pyrimidine derivatives containing thiosemicarbazide moiety $5 a-d$ were synthesized and evaluated for their in vitro antitumor activity against two human cancer cell lines.

\section{Results and Discussion}

The synthetic strategies adopted for the synthesis of the intermediate and final compounds are illustrated in Scheme 1. The starting compound, ethyl 2-amino-4,5,6,7-tetrahydro [1] benzothiophene-3-carboxylate (1) was prepared according to the well-known Gewald procedure [17]. Reacting 1 with benzyl isothiocyanate in acetonitrile afforded the corresponding 3-benzyl-2-sulfanylthienopyrimidine derivative 2 [18]. Reacting 2 with ethyl

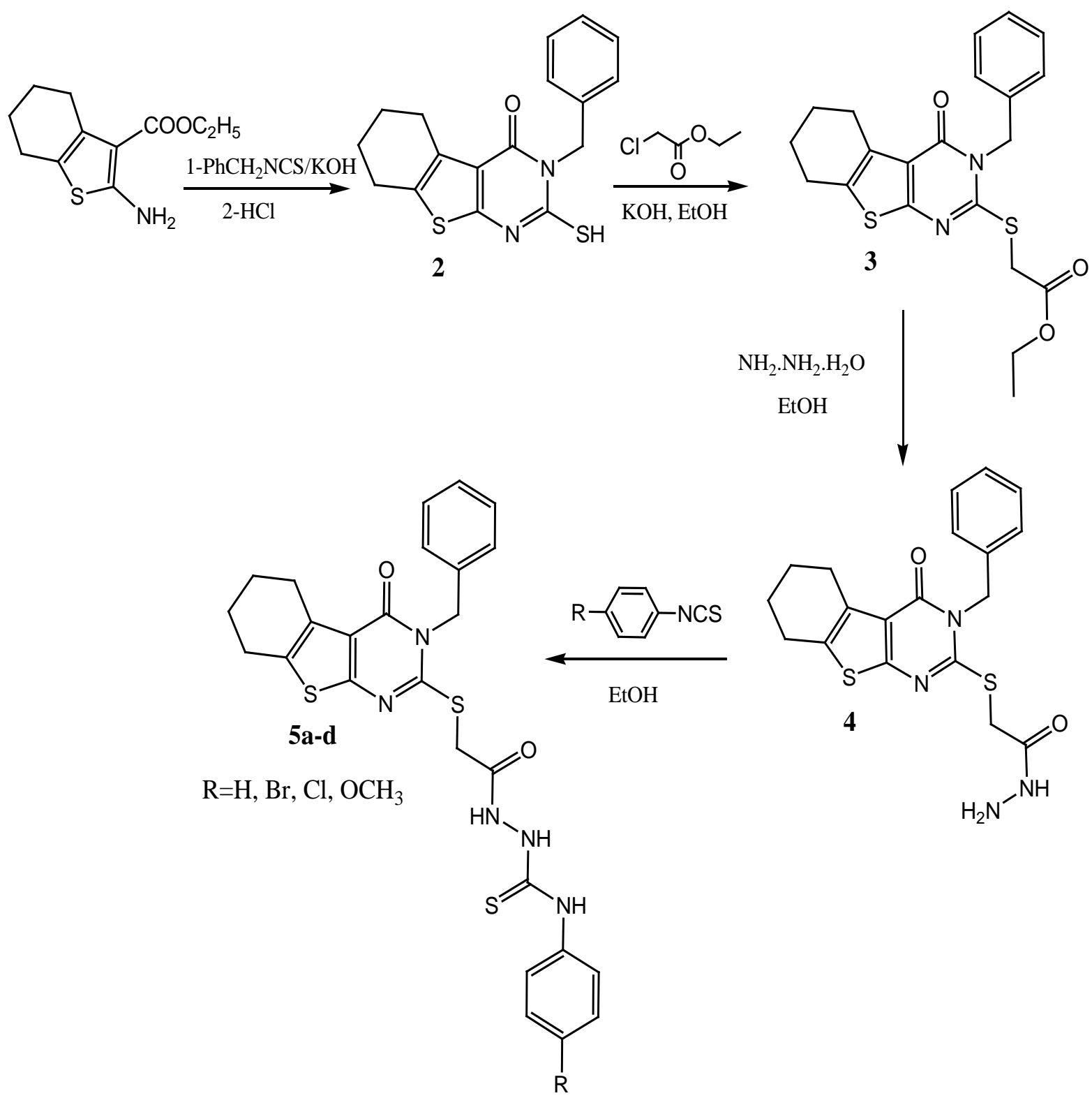


chloroacetate in the presence of $\mathrm{KOH}$ followed by acidification with dil. $\mathrm{HCl}$ yielded the ester $\mathbf{3}$ according to Devani et al. [18]. Heating 3 with 99\% hydrazine hydrate under reflux yielded the hydrazide derivative $\mathbf{4}$. The structure of compound 4 was confirmed by IR and ${ }^{1} \mathrm{H}-\mathrm{NMR}$ spectroscopy. IR spectrum showed broad band in the range of $v 3296-3200 \mathrm{~cm}^{-1}$ which indicated the presence of $\mathrm{NH}$ and $\mathrm{NH}_{2}$. Peaks around $v 1674$ and 1647 $\mathrm{cm}^{-1}$ are due to the two carbonyl moieties. ${ }^{1} \mathrm{H}$-NMR spectrum showed the presence of two exchangeable protons overlapped with C6 and C7 of cyclohexanyl protons in the range of $\delta 1.76-1.80 \mathrm{ppm}$ indicating the $\mathrm{NH}_{2}$ in addition to one exchangeable proton at $\delta 9.33 \mathrm{ppm}$ corresponding to the $\mathrm{NH}$. The mass spectrum displayed the molecular ion at $\mathrm{m} / \mathrm{z}=400(0.92 \%)$ and the base peak at $\mathrm{m} / \mathrm{z}=91(100 \%)$. The key intermediate 4 was readily converted to the thiosemicarbazide derivatives 5a-d by heating it with the appropriate aryl isothiocyanates in ethanol under reflux. A special feature in the structure of thiosemicarbazides is the presence of thiourea residue (NH-CS-NH), which can be identified by IR spectral data. Compounds 5a-d exhibited strong absorption in the range of $v 1151-1195 \mathrm{~cm}^{-1}$ attributable to $\mathrm{C}=\mathrm{S}$. Bands around $v 1680$ and $1650 \mathrm{~cm}^{-1}$ accounts for the two carbonyl groups of the pyrimidinone ring and the acetyl thiosemicarbazide respectively. ${ }^{1} \mathrm{H}-\mathrm{NMR}$ spectra of 5a-d showed a singlet signal at $\delta 4.1 \mathrm{ppm}$ assignable to $-\mathrm{CH}_{2}$ - flanked between the thienopyrimidin-2-ylsulphanyl group and carbonyl function. The three $\mathrm{D}_{2} \mathrm{O}$ exchangeable signals for the $\mathrm{NH}$ functions were displayed in the range of $\delta 9.40-10.69 \mathrm{ppm}$. In addition, the presence of $\mathrm{OCH}_{3}$ group in $\mathbf{5 d}$ was confirmed by the presence of a singlet signal at $\delta 3.77 \mathrm{ppm}$. Besides, two doublets in the range of $\delta 6.49-6.88 \mathrm{ppm}$ and $\delta 6.98-7.21$ ppm were assignable to p-disubstituted phenyl ring in compounds $\mathbf{5 b}-\mathbf{d}$.

\section{Experimental}

All Melting points were determined with Stuart SMP10 apparatus and the values given are uncorrected. IR spectra $\left(\mathrm{KBr}, \mathrm{cm}^{-1}\right)$ were determined on Shimadzu IR 8400s spectrophotometer (Faculty of Pharmacy, Cairo University, Egypt). ${ }^{1} \mathrm{H}-\mathrm{NMR}$ and ${ }^{13} \mathrm{C}-\mathrm{NMR}$ spectra were recorded on Mercury 300-BB $300 \mathrm{MHz}$ (Microanalytical Center, Cairo University, Egypt) and Bruker 400-BB 400 MHz (Microanalytical Unit, Faculty of Pharmacy, Cairo University, Egypt) spectrophotometers using TMS as an internal standard. Chemical shift values are recorded in ppm on $\delta$ scale. Mass spectra were recorded on Hewlett Packard 5988 spectrometer (Microanalytical Center, Cairo University, Egypt). Elemental analyses were carried out at the Regional center for Mycology and Biotechnology, Faculty of Pharmacy, Al Azhar University, Egypt; found values were within $\pm 0.35 \%$ of the theoretical ones. Progress of the reactions was monitored by TLC (Thin Layer Chromatography) using aluminum sheets precoated with UV fluorescent silica gel (Merck 60F 254) and visualized using UV lamp. The solvent system used was chloroform: benzene: methanol [9:5:2].

The starting compounds, Ethyl 2-amino-4,5,6,7-tetrahydro[1]benzothiophene-3-carboxylate (1) [17], 3-benzyl-2-sulphanyl-5,6,7,8-tetrahydro[1]benzothieno[2,3-d]pyrimidin-4(3H)-one (2) [18] and 2-Ethoxycarbonyl methylthio-3-benzyl-5,6,7,8-tetrahydro[1]benzothieno[2,3-d]pyrimidin-4(3H)-one (3) [18] were prepared according to reported procedures.

2-(3-benzyl-4-oxo(3H)-5,6,7,8-tetrahydro [1]benzothieno[2,3-d]pyrimidin-2-ylsulphanyl) acetohydrazide (4)

The ester $3(0.82 \mathrm{~g}, 0.002 \mathrm{~mol})$ was dissolved in absolute ethanol $(25 \mathrm{ml})$ then hydrazine hydrate $(99 \%$ $100 \%)(0.5 \mathrm{~g}, 0.48 \mathrm{ml}, 0.01 \mathrm{~mol})$ was added and the reaction mixture was stirred in a water bath at $70^{\circ} \mathrm{C}-80^{\circ} \mathrm{C}$ for $1 \mathrm{~h}$ and then for additional $25 \mathrm{~h}$ at room temperature. The precipitate formed was filtered, dried and recrystallized from benzene/ absolute ethanol (1:2).

Yield: 53\%; mp: $138^{\circ} \mathrm{C}-140^{\circ} \mathrm{C}$; IR (KBr, cm $\left.{ }^{-1}\right)$ : $3296-3200\left(\mathrm{NH}\right.$ and $\mathrm{NH}_{2}$ str.), 3062, 3030 (CH aromatic str.), 2924, 2850 (CH aliphatic str.), 1674, 1647 (2 C = O str.); ${ }^{1} \mathrm{H}-\mathrm{NMR}$ (DMSO- $\left.d_{6}\right) \delta: 1.76-1.80$ (m, 6H, 2 $\mathrm{CH}_{2}$ at C-6, C-7 \& $\left.\mathrm{NH}_{2}\right), 2.72-2.78\left(\mathrm{~m}, 2 \mathrm{H}, \mathrm{CH}_{2}\right.$ at C-5), $2.85-2.87$ (m, $2 \mathrm{H}, \mathrm{CH}_{2}$ at C-8), $3.91\left(\mathrm{~s}, 2 \mathrm{H}, \underline{\mathrm{SCH}}_{2}\right)$, 5.30 (s, $2 \mathrm{H}, \mathrm{NCH}_{2} \mathrm{C}_{6} \mathrm{H}_{5}$ ), 7.22 - 7.36 (m, 5H, Ar-H), 9.33 (s, $1 \mathrm{H}, \mathrm{NH}, \mathrm{D}_{2} \mathrm{O}$ exchangeable); EIMS (\% rel. abundance): $400\left(\mathrm{M}^{+}, 0.92\right), 91\left(\mathrm{C}_{7} \mathrm{H}_{7}{ }^{1+}, 100\right)$; Anal. Calcd for $\mathrm{C}_{19} \mathrm{H}_{20} \mathrm{~N}_{4} \mathrm{O}_{2} \mathrm{~S}_{2}$ (400.52): C, 56.98; H, 5.03; N, 13.99 . Found: C, 57.13; H, 5.09; N, 14.17 .

General procedure for synthesis of 4-aryl-1-[2-(3-benzyl-4-oxo(3H)-5,6,7,8-tetrahydro[1]benzothieno[2,3-d] pyrimidin-2-ylsulphanyl) acetyl] thiosemicarbazide (5a-d)

To a solution of the hydrazide $4(0.4 \mathrm{~g}, 0.001 \mathrm{~mol})$ in absolute ethanol $(55 \mathrm{ml})$, the appropriate isothiocyanate $(1.2 \mathrm{mmol})$ was added and the reaction mixture was heated under reflux for $5-8 \mathrm{~h}$. The product precipitated while heating was filtered then stirred with absolute ethanol at room temperature for 30 minutes for purification.

4-Phenyll-1-[2-(3-benzyl-4-oxo(3H)-5,6,7,8-tetrahydro[1]benzothieno[2,3-d]pyrimidin-2-ylsulphanyl)acetyl] thiosemicarbazide (5a) 
IR (KBr, $\left.\mathrm{cm}^{-1}\right)$ : 3325-3226 (NH str.), 3080, 3040 (CH aromatic str.), 2918, 2848 (CH aliphatic str.), 1683, 1656 (2 C = O str.), 1624 (C = N str.), 1153 (C = S str.); ${ }^{1} \mathrm{H}-\mathrm{NMR}$ (DMSO- $\left.d_{6}\right) \delta: 1.78-1.85$ (m, 4H, $2 \mathrm{CH}_{2}$ at C-6, C-7), $2.72-2.80\left(\mathrm{~m}, 2 \mathrm{H}, \mathrm{CH}_{2}\right.$ at C-5), $2.85-2.88\left(\mathrm{~m}, 2 \mathrm{H}, \mathrm{CH}_{2}\right.$ at C-8), $4.10\left(\mathrm{~s}, 2 \mathrm{H}, \mathrm{SCH}_{2}\right), 5.33(\mathrm{~s}, 2 \mathrm{H}$, $\mathrm{NCH}_{2} \mathrm{C}_{6} \mathrm{H}_{5}$ ), 7.16-7.44 (m, 10H, Ar-H), 9.50, 9.70, 10.34 (each s, 3H, 3NH, $\mathrm{D}_{2} \mathrm{O}$ exchangeable); EIMS (\% rel. abundance): $535\left(\mathrm{M}^{+}, 35.80\right), 91\left(\mathrm{C}_{7} \mathrm{H}_{7}{ }^{1+}, 100\right)$.

4-(4-Bromophenyl)-1-[2-(3-benzyl-4-oxo(3H)-5,6,7,8-tetrahydro[1]benzothieno[2,3-d]pyrimidin-2-ylsulphany l) acetyl] thiosemicarbazide (5b)

IR ( $\mathrm{KBr}, \mathrm{cm}^{-1}$ ): 3194-3107 (NH str.), 3062, 3001 (CH aromatic str.), 2935, 2850 (CH aliphatic str.), 1681, 1650 (2 C = O str.), 1583 (C = C aromatic str.), 1193 (C = S str.); ${ }^{1} \mathrm{H}-\mathrm{NMR}$ (DMSO-d ${ }_{6}$ ) $\delta: 1.78-1.83$ (m, 4H, 2 $\mathrm{CH}_{2}$ at C-6, C-7), 2.70 - $2.79\left(\mathrm{~m}, 2 \mathrm{H}, \mathrm{CH}_{2}\right.$ at C-5), $2.82-2.86\left(\mathrm{~m}, 2 \mathrm{H}, \mathrm{CH}_{2}\right.$ at C-8), $4.10\left(\mathrm{~s}, 2 \mathrm{H}, \mathrm{SCH}_{2}\right), 5.33$ (s, $2 \mathrm{H}, \mathrm{NCH}_{2} \mathrm{C}_{6} \mathrm{H}_{5}$ ), 6.50 (d, 2H, $\left.J=9 \mathrm{~Hz}, \mathrm{Ar}-\mathrm{H}\right), 7.11$ (d, 2H, $\left.J=9 \mathrm{~Hz}, \mathrm{Ar}-\mathrm{H}\right), 7.38$ - 7.59 (m, 5H, Ar-H), 10.25, 10.60, 10.69 (each s, 3H, 3NH, $\mathrm{D}_{2} \mathrm{O}$ exchangeable); EIMS (\% rel. abundance): $615(\mathrm{M}+2,1.62), 613\left(\mathrm{M}^{+}, 1.83\right)$, $295\left(\mathrm{C}_{17} \mathrm{H}_{15} \mathrm{~N}_{2} \mathrm{OS}^{1+}, 100\right)$.

4-(4-Chlorophenyl)-1-[2-(3-benzyl-4-oxo(3H)-5,6,7,8-tetrahydro[1]benzothieno[2,3-d]pyrimidin-2-ylsulphany l) acetyl] thiosemicarbazide (5c)

IR ( $\mathrm{KBr}, \mathrm{cm}^{-1}$ ): 3321 - 3107 (NH str.), 3028, 3010 (CH aromatic str.), 2926, 2850 (CH aliphatic str.), 1689, 1654 (2 C = O str.), 1620 (C = N str.), 1195 (C = S str.); ${ }^{1} \mathrm{H}-\mathrm{NMR}$ (DMSO-d $\left.{ }_{6}\right) \delta: 1.78-1.82\left(\mathrm{~m}, 4 \mathrm{H}, 2 \mathrm{CH}_{2}\right.$ at C-6, C-7), 2.70-2.78 (m, 2H, CH 2 at C-5), $2.85-2.88$ (m, 2H, $\mathrm{CH}_{2}$ at C-8), 4.11 (s, $\left.2 \mathrm{H}, \mathrm{SCH}_{2}\right), 5.32$ (s, $2 \mathrm{H}$, $\mathrm{NCH}_{2} \mathrm{C}_{6} \mathrm{H}_{5}$ ), 6.54 (d, $\left.2 \mathrm{H}, J=8.7 \mathrm{~Hz}, \mathrm{Ar}-\mathrm{H}\right), 7.0$ (d, 2H, $\left.J=9 \mathrm{~Hz}, \mathrm{Ar}-\mathrm{H}\right), 7.23$ - 7.63 (m, 5H, Ar-H), 9.91, 10.25, 10.42 (each s, 3H, 3NH, $\mathrm{D}_{2} \mathrm{O}$ exchangeable); ${ }^{13} \mathrm{C}$ NMR (DMSO-d $\left.d_{6} \mathrm{ppm}\right) \delta: 21.66,22.36,24.35,25.12\left(4 \mathrm{CH}_{2}\right.$ of cyclohexane), $38.67\left(\mathrm{SCH}_{2}\right), 40.35\left(\mathrm{NCH}_{2} \mathrm{C}_{6} \mathrm{H}_{5}\right), 118.32\left(\mathrm{C}_{4 \mathrm{a}}\right), 124.43\left(\mathrm{C}_{5 \mathrm{a}}\right), 126.45$ (benzyl- $\left.\mathrm{C}_{4}\right), 127.81$ (benzyl- $\mathrm{C}_{2}, \mathrm{C}_{6}$ ), 127.94 (phenyl- $\mathrm{C}_{2}, \mathrm{C}_{6}$ ), 128.27 (benzyl- $\mathrm{C}_{3}, \mathrm{C}_{5}$ ), 128.48 (phenyl- $\mathrm{C}_{3}, \mathrm{C}_{5}$ ), 131.09 (phenyl- $\mathrm{C}_{4}$ ), 138.17 (phenyl- $\left.\mathrm{C}_{1}\right), 138.27\left(\mathrm{C}_{8 \mathrm{a}}\right), 138.62$ (benzyl- $\left.\mathrm{C}_{1}\right), 139.94\left(\mathrm{C}_{9 \mathrm{a}}\right), 146.79\left(\mathrm{C}_{2}\right), 155.57(\mathrm{C}=\mathrm{O}$ pyrimidinone ring), $156.01(\mathrm{C}=\mathrm{O}), 181.43(\mathrm{C}=\mathrm{S})$; EIMS (\% rel. abundance): $571(\mathrm{M}+2,0.8), 569\left(\mathrm{M}^{+}, 15.65\right)$.

4-(4-methoxyphenyl)-1-[2-(3-benzyl-4-oxo(3H)-5,6,7,8-tetrahydro[1]benzothieno[2,3-d] pyrimidin-2-ylsulpha nyl) acetyl] thiosemicarbazide (5d) (Table 1$)$

IR ( $\mathrm{KBr}, \mathrm{cm}^{-1}$ ): 3317-3122 (NH str.), 3030, 3010 (CH aromatic str.), 2927, 2833 (CH aliphatic str.), 1687, 1654 (2 C = O str.), 1622 (C = N str.), 1151 (C = S str.); $1 \mathrm{H}-\mathrm{NMR}$ (DMSO-d $\left.\mathrm{d}_{6}\right) \delta: 1.77-1.81\left(\mathrm{~m}, 4 \mathrm{H}, 2 \mathrm{CH}_{2}\right.$ at C-6, C-7), 2.69 - $2.79\left(\mathrm{~m}, 2 \mathrm{H}, \mathrm{CH}_{2}\right.$ at C-5), $2.85-2.87\left(\mathrm{~m}, 2 \mathrm{H}, \mathrm{CH}_{2}\right.$ at C-8), 3.77 (s, 3H, $\left.\mathrm{OCH}_{3}\right), 4.10$ (s, $2 \mathrm{H}$, $\mathrm{SCH}_{2}$ ), 5.33 (s, $2 \mathrm{H}, \mathrm{NCH}_{2} \mathrm{C}_{6} \mathrm{H}_{5}$ ), 6.87 (d, $\left.2 \mathrm{H}, J=9 \mathrm{~Hz}, \mathrm{Ar}-\mathrm{H}\right), 7.20$ (d, $\left.2 \mathrm{H}, J=9 \mathrm{~Hz}, \mathrm{Ar}-\mathrm{H}\right), 7.23$ - 7.37 (m, 5H, Ar-H), 9.40, 9.60, 10.32 (each s, 3H, 3NH, $\mathrm{D}_{2} \mathrm{O}$ exchangeable).; EIMS (\% rel. abundance): 565 ( $\mathrm{M}^{+}, 3.47$ ).

\section{Biological Activity}

\section{Anticancer Screening}

The cytotoxic activity of the synthesized compounds was evaluated in vitro against human prostate cancer cell

Table 1. Physical and analytical properties of compounds 5a-d.

\begin{tabular}{|c|c|c|c|c|c|c|}
\hline \multirow{2}{*}{ Compound } & \multirow{2}{*}{$\mathbf{R}$} & \multirow{2}{*}{$\mathbf{m p}\left({ }^{\circ} \mathbf{C}\right)$} & \multirow{2}{*}{ Yield (\%) } & \multirow{2}{*}{ Molecular formula (M.wt) } & \multicolumn{2}{|c|}{ Analysis \% } \\
\hline & & & & & Calcd & Found \\
\hline $5 a$ & $\mathrm{H}$ & $240-242$ & 33 & $\begin{array}{c}\mathrm{C}_{26} \mathrm{H}_{25} \mathrm{~N}_{5} \mathrm{O}_{2} \mathrm{~S}_{3} \\
535.70\end{array}$ & $\begin{array}{c}\text { C } 58.29 \\
\text { H } 4.70 \\
\text { N } 13.07\end{array}$ & $\begin{array}{c}58.38 \\
4.76 \\
13.23\end{array}$ \\
\hline $5 b$ & $\mathrm{Br}$ & $194-196$ & 46 & $\begin{array}{c}\mathrm{C}_{26} \mathrm{H}_{24} \mathrm{BrN}_{5} \mathrm{O}_{2} \mathrm{~S}_{3} \\
615.61\end{array}$ & $\begin{array}{c}\text { C } 50.81 \\
\text { H } 3.94 \\
\text { N } 11.39\end{array}$ & $\begin{array}{c}50.87 \\
3.92 \\
11.54\end{array}$ \\
\hline $5 c$ & $\mathrm{Cl}$ & $204-206$ & 50 & $\begin{array}{c}\mathrm{C}_{26} \mathrm{H}_{24} \mathrm{ClN}_{5} \mathrm{O}_{2} \mathrm{~S}_{3} \\
570.15\end{array}$ & $\begin{array}{c}\text { C } 54.77 \\
\text { H } 4.24 \\
\text { N } 12.28\end{array}$ & $\begin{array}{c}54.86 \\
4.26 \\
12.39\end{array}$ \\
\hline $5 d$ & $\mathrm{OCH}_{3}$ & $206-208$ & 62 & $\begin{array}{c}\mathrm{C}_{27} \mathrm{H}_{27} \mathrm{~N}_{5} \mathrm{O}_{3} \mathrm{~S}_{3} \\
565.73\end{array}$ & $\begin{array}{c}\text { C } 57.32 \\
\text { H } 4.81 \\
\text { N } 12.38\end{array}$ & $\begin{array}{c}57.43 \\
4.79 \\
12.52\end{array}$ \\
\hline
\end{tabular}


line (PC-3) and colon cancer cell line (HCT-116) at five different doses (0, 5, 12.5, $25 \& 50 \mu \mathrm{g} / \mathrm{ml}$ ). The screening was carried out at the Pharmacology Unit, Cancer Biology Department, National Cancer Institute, Cairo University using Sulforhodamine-B (SRB) assay, applying the method of Skehan et al. [19] as follows:

Cells were plated in 96 multi-well plate (104 cells/well) for $24 \mathrm{~h}$ before treatment with the tested compound to allow attachment to the wall of the plate. Different concentrations of the compounds $(0,5,12.5,25$ and $50 \mu \mathrm{g}$ $/ \mathrm{ml}$ ) were added to the cell monolayer in triplicate and wells were prepared for each individual dose. Monolayer cells were incubated with the compounds for $48 \mathrm{~h}$ at $37^{\circ} \mathrm{C}$ in atmosphere of $5 \% \mathrm{CO}_{2}$. After $48 \mathrm{~h}$, cells were fixed, washed and stained with Sulforhodamine-B stain. Excess stain was washed with acetic acid and the attached stain was recovered with Tris EDTA buffer. Color intensity was measured in an ELISA reader. The relation between surviving fraction and drug concentration is plotted to get the survival curve of each tumor cell line. For each tested compound, $\mathrm{IC}_{50}$ (the concentration required for $50 \%$ inhibition of cell viability) was calculated.

The in vitro cytotoxic activity of the synthesized compounds was evaluated against two human cancer cell lines including cells derived from human prostate cancer (PC-3) and human colon cancer (HCT-116). For comparison purposes, the cytotoxicity of doxorubicin, which is one of the most effective anticancer agents [20], was evaluated under the same conditions. The relationship between the surviving fraction and drug concentration was plotted to obtain the survival curve of prostate cancer cell line (PC-3) and colon carcinoma cell line (HCT-116). The response parameter calculated was the $\mathrm{IC}_{50}$ value, which corresponds to the concentration required for $50 \%$ inhibition of cell viability. Values were calculated from dose-response curves done in triplicates for each compound. The $\mathrm{IC}_{50}$ values in $\mu \mathrm{g} / \mathrm{ml}$ and $\mu \mathrm{M}$ are listed in (Table 2 and Table 3) and the results are represented graphically in (Figure 1).

From the analysis of the in vitro observed data, it was found, interestingly, that the bromophenyl derivative $\mathbf{5 b}$ was the most active against both PC-3 and HCT-116 cell lines, while the unsubstituted phenyl derivative 5a was the least active against both cell lines. It is clear from the results of cytotoxic screening that the substitution on position 4 of the phenyl ring of thiosemicarbazide moiety is essential for the cytotoxic activity against both cell lines where the substituted derivatives $\mathbf{5 b}$-d exhibited higher activity compared to the phenyl analogue 5a. It

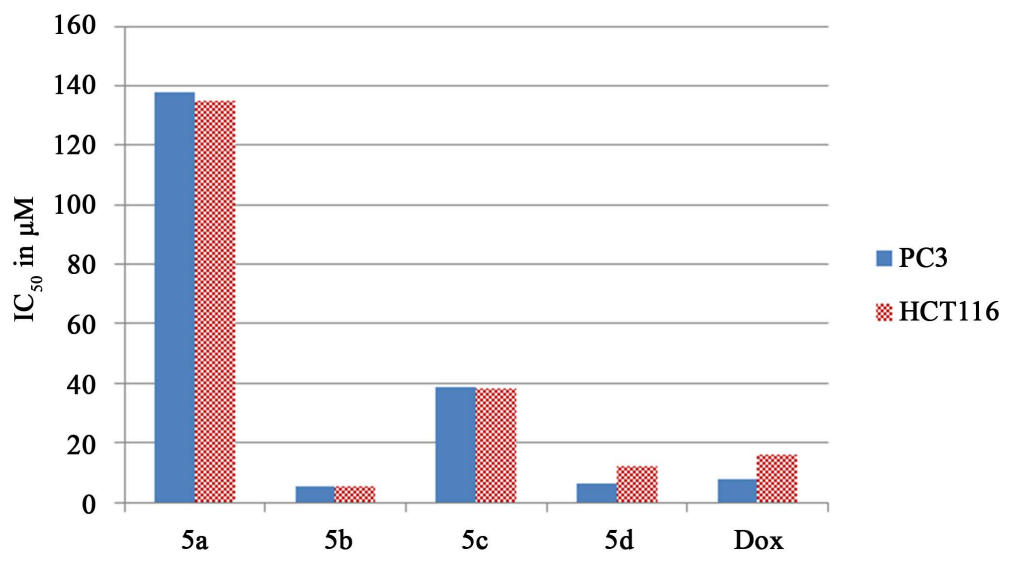

Figure 1. Anticancer activity of the synthesized compounds against PC-3 and HCT-116 cell lines compared to Dox.

Table 2. Results of in vitro cytotoxicity of compounds 5a-d against human prostate cancer cell line (PC-3).

\begin{tabular}{|c|c|c|c|c|c|c|c|}
\hline \multirow{2}{*}{$\begin{array}{l}\text { Compound } \\
\text { number }\end{array}$} & \multicolumn{5}{|c|}{ Percentage of the surviving PC-3 cells at each concentration in $\mu \mathrm{g} / \mathrm{ml}$} & \multirow{2}{*}{$\underset{(\mu \mathrm{g} / \mathrm{ml})}{\mathrm{IC}_{50}}$} & \multirow{2}{*}{$\begin{array}{l}\mathrm{IC}_{50} \\
(\mu \mathrm{M})\end{array}$} \\
\hline & 0 & 5 & 12.5 & 25 & 50 & & \\
\hline $5 a$ & 1.00 & 0.953 & 0.872 & 0.725 & 0.537 & 73.92 & 138 \\
\hline $5 \mathbf{b}$ & 1.00 & 0.310 & 0.290 & 0.282 & 0.242 & 3.28 & 5.33 \\
\hline $5 c$ & 1.00 & 0.876 & 0.605 & 0.381 & 0.207 & 22.17 & 38.9 \\
\hline $5 d$ & 1.00 & 0.297 & 0.297 & 0.277 & 0.240 & 3.58 & 6.32 \\
\hline Dox & 1.00 & 0.426 & 0.554 & 0.462 & 0.467 & 4.2 & 7.7 \\
\hline
\end{tabular}


Table 3. Results of in vitro cytotoxicity of compounds 5a-d against human colon cancer cell line (HCT-116).

\begin{tabular}{|c|c|c|c|c|c|c|c|}
\hline \multirow{2}{*}{$\begin{array}{l}\text { Compound } \\
\text { number }\end{array}$} & \multicolumn{5}{|c|}{ Percentage of the surviving HCT-116 at each concentration in $\mu \mathrm{g} / \mathrm{ml}$} & \multirow{2}{*}{$\begin{array}{c}\mathrm{IC}_{50} \\
(\mu \mathrm{g} / \mathrm{ml})\end{array}$} & \multirow{2}{*}{$\begin{array}{l}\mathrm{IC}_{50} \\
(\mu \mathrm{M})\end{array}$} \\
\hline & $\mathbf{0}$ & 5 & 12.5 & 25 & 50 & & \\
\hline $5 a$ & 1.00 & 0.890 & 0.701 & 0.665 & 0.533 & 72.31 & 135 \\
\hline $5 \mathbf{b}$ & 1.00 & 0.352 & 0.2779 & 0.234 & 0.223 & 3.28 & 5.33 \\
\hline $5 c$ & 1.00 & 0.906 & 0.752 & 0.356 & 0.207 & 21.66 & 38 \\
\hline 5d & 1.00 & 0.602 & 0.317 & 0.234 & 0.195 & 6.78 & 11.98 \\
\hline Dox & 1.00 & 0.627 & 0.400 & 0.375 & 0.372 & 8.6 & 15.82 \\
\hline
\end{tabular}

was observed that replacement of the $\mathrm{Br}$ in position 4 of phenyl ring with $\mathrm{Cl}$ resulted in decrease in activity where compound $\mathbf{5 b}$ (substituted with $\mathbf{B r}$ ) displayed much more potent anticancer activity than $\mathbf{5 c}$ (substituted with $\mathrm{Cl}$ ) against both cell lines. Moreover, compound $\mathbf{5 b}$ exhibited 1.5-fold more potent antitumor activity against PC-3 cell line and 3-fold more potent activity against HCT-116 cell line than DOX. In addition, compound 5c showed moderate activity $\left(\mathrm{IC}_{50} 38 \mu \mathrm{M}\right)$ against both cell lines. It was found that the $4-\mathrm{OCH}_{3}$ analogue 5d displayed 1.2-fold more potent activity against PC-3 cell line and 1.3-fold more potent activity against HCT-116 cell line in comparison with DOX.

\section{Conclusion}

A series of thienopyrimidine derivatives linked to thiosemicarbazide moiety was synthesized, characterized and evaluated for their in vitro anticancer activity against two human cancer cell lines (prostate and colon cancer cell lines). Compounds $5 \mathrm{~b}$ and $5 \mathrm{~d}$ showed higher cytotoxic activity against both PC-3 and HCT-116 cell lines compared to DOX. The incorporation of $\mathrm{Br}$ in position 4 of phenyl ring in thiosemicarbazide moiety was found to significantly enhance the anticancer activity where compound $5 \mathrm{~b}$ displayed 1.5 -fold more potent activity against PC-3 and 3-fold higher activity against HCT-116 compared to the standard drug DOX. In addition, the incorporation of $\mathrm{OCH}_{3}$ group obviously increased the activity against both cell lines than DOX. The obtained results suggest that thieno[2,3- $d$ ]pyrimidines containing thiosemicarbazide scaffold might be suitable candidates for further chemical modification in order to obtain more potent and selective anticancer agents.

\section{Acknowledgements}

The authors gratefully acknowledge the department of Cancer Biology, National Cancer Institute, Cairo, Egypt, for carrying out the anticancer screening.

\section{References}

[1] Eckhardt, S. (2002) Recent Progress in the Development of Anticancer Agents. Current Medicinal Chemistry-AntiCancer Agents, 2, 419-439. http://dx.doi.org/10.2174/1568011024606389

[2] Abdel-Aziz, A.A.-M. (2007) Novel and Versatile Methodology for Synthesis of Cyclic Imides and Evaluation of Their Cytotoxic, DNA Binding, Apoptotic Inducing Activities and Molecular Modeling Study. European Journal of Medicinal Chemistry, 42, 614-626. http://dx.doi.org/10.1016/j.ejmech.2006.12.003

[3] Choo, H.-Y.P., Kim, M., Lee, S.K., Kim, S.W. and Chung, I.K. (2002) Solid-Phase Combinatorial Synthesis and Cytotoxicity of 3-Aryl-2,4-quinazolindiones. Bioorganic \& Medicinal Chemistry, 10, 517-523. http://dx.doi.org/10.1016/S0968-0896(01)00299-1

[4] Zhou, B.B.S., Huang, H., Damelin, M., Geles, K.G., Grindley, J.C. and Dirks, P.B. (2009) Tumour-Initiating cells: Challenges and Opportunities for Anticancer Drug Discovery. Nature Reviews Drug Discovery, 8, 506-523. http://dx.doi.org/10.1038/nrd2137

[5] Liu, L.T., Yuan, T.T., Liu, H.H., Chen, S.F. and Wu, Y.T. (2007) Synthesis and Biological Evaluation of Substituted 6-Alkynyl-4-anilinoquinazoline Derivatives as Potent EGFR Inhibitors. Bioorganic \& Medicinal Chemistry Letters, 17, 6373-6377. http://dx.doi.org/10.1016/j.bmcl.2007.08.061

[6] Wakeling, A.E., Guy, S.P., Woodburn, J.R., Ashton, S.E., Curry, B.J., Barker, A.J. and Gibson, K.H. (2002) ZD1839 (Iressa): An Orally Active Inhibitor of Epidermal Growth Factor Signaling with Potential for Cancer Therapy. Cancer 
Research, 62, 5749-5754.

[7] Moyer, J.D., Barbacci, E.G., Iwata, K.K., Arnold, L., Boman, B., Cunningham, A., Diorio, C., Doty, J., Morin, M.J., Moyer, M.P., Neveu, M., Pollack, V.A., Pustilink, L.R., Reynolds, M.M., Salon, D., Theleman, A. and Miller, P. (1997) Induction of Apoptosis and Cell Cycle Arrest by CP-358,774, an Inhibitor of Epidermal Growth Factor Receptor Tyrosine Kinase. Cancer Research, 57, 4838-4848.

[8] De Angelo, D.J., Stone, R.M., Heany, M.L., Nimer, S.D., Paquette, R.L., Klisovic, R.B., Caligiuri, M.A., Cooper, M.R., Leverf, J., Karol, M.D., Sheng, S., Holford, N., Curtin, P.T., Druker, B.J. and Heinrich, M.C. (2006) Phase 1 Clinical Results with Tandutinib (MLN518), a Novel FLT3 Antagonist, in Patients with Acute Myelogenous Leukemia or High-Risk Myelodysplastic Syndrome: Safety, Pharmacokinetics, and Pharmacodynamics. Blood, 108, 3674-3681. http://dx.doi.org/10.1182/blood-2006-02-005702

[9] Katada, J., Iijima, K., Muramatsu, M., Takami, M., Yasuda, E., Hayashi, M., Hattori, M. and Hayashi, Y. (1999) Cytotoxic Effects of NSL-1406, a New Thienopyrimidine Derivative, on Leukocytes and Osteoclasts. Bioorganic \& Medicinal Chemistry Letters, 9, 797-802. http://dx.doi.org/10.1016/S0960-894X(99)00088-8

[10] Gangjee, A., Qiu, Y. and Kisliuk, R.L. (2004) Synthesis of Classical and Nonclassical 2-Amino-4-oxo-6-benzylthieno[2,3-d]pyrimidines as Potential Thymidylate Synthase Inhibitors. Journal of Heterocyclic Chemistry, 41, 941-946. http://dx.doi.org/10.1002/jhet.5570410613

[11] Dai, R.L., Guo, Y., Frey, R.R., Ji, Z., Curtin, M.L., Ahmed, A.A., Albert, D.H., Arnold, L., Arries, S.S., Barlozzari, T., Bauch, J.L., Bouska, J.J., Bousquet, P.F., Cunha, G.A., Glaser, K.B., Guo, J., Li, J., Marcotte, P.A., Marsh, K.C., Moskey, M.D., Pease, L.J., Stewart, K.D., Stoll, V.S., Tapang, P., Wishart, N., Davidsen, S.K. and Michaelides, M.R. (2005) Thienopyrimidine Ureas as Novel and Potent Multitargeted Receptor Tyrosine Kinase Inhibitors. Journal of Medicinal Chemistry, 48, 6066-6083. http://dx.doi.org/10.1021/jm050458h

[12] Wang, Y.D., Johnson, S., Powell, D., McGinnis, J.P., Miranda, M. and Rabindran, S.K. (2005) Inhibition of Tumor Cell Proliferation by Thieno[2,3-d]pyrimidin-4(1H)-one-based Analogs. Bioorganic \& Medicinal Chemistry Letters, 15, 3763-3766. http://dx.doi.org/10.1016/j.bmcl.2005.05.127

[13] Jennings, L.D., Kincaid, S.L., Wang, Y.D., Krishnamurthy, G., Beyer, C.F., McGinnis, J.P., Miranda, M., Discafani, C.M. and Rabindran, S.K. (2005) Parallel Synthesis and Biological Evaluation of 5,6,7,8-Tetrahydrobenzothieno[2,3d]pyrimidin-4(3H)-one Cytotoxic Agents Selective for p21-Deficient Cells. Bioorganic \& Medicinal Chemistry Letters, 15, 4731-4735. http://dx.doi.org/10.1016/j.bmcl.2005.07.072

[14] Nandi, A.K., Chaudhri, S., Mazumdah, S.K. and Ghosh, S. (1984) Effect of Chlorine Substitution on the Structure and Activity of 4-Phenylthiosemicarbazide: Crystal and Molecular Structure of 4-(4-Chlorophenyl) Thiosemicarbazide. Journal of the Chemical Society, Perkin Transactions 2, No. 11, 1729-1733. http://dx.doi.org/10.1039/p29840001729

[15] Ali, M.A., Chowdhary-I, D.A. and Uddin, M.N. (1984) Four- and Five-Coordinate Copper (II) Complexes Containing Mixed Ligands. Polyhedron, 3, 595-598. http://dx.doi.org/10.1016/S0277-5387(00)88093-6

[16] Scovill, J.P., Klayman, D.L. and Franchino, C.F. (1982) 2-Acetylpyridine Thiosemicarbazones. 4. Complexes with Transition Metals as Antimalarial and Antileukemic Agents. Journal of Medicinal Chemistry, 25, 1261-1264. http://dx.doi.org/10.1021/jm00352a036

[17] Gewald, K. (1965) Heterocyclen aus CH-aciden Nitrilen, VII. 2-Amino-thiophene aus $\alpha$-Oxo-mercaptanen und Methylenaktiven Nitrilen. Chemische Berichte, 98, 3571-3577. http://dx.doi.org/10.1002/cber.19650981120

[18] Devani, M.B., Shishoo, C.J., Pathak, U.S., Parikh, S.H., Shah, G.F. and Padhya, A.C. (1976) Synthesis of 3-Substituted Thieno[2,3-d]pyrimidin-4(3H)-one-2-mercaptoacetic Acids and Their Ethyl Esters for Pharmacological Screening. Journal of Pharmaceutical Sciences, 65, 660-664. http://dx.doi.org/10.1002/jps.2600650507

[19] Skehan, P., Storeng, R., et al. (1990) New Colorimetric Cytotoxicity Assay for Anticancer-Drug Screening. Journal of National Cancer Institute, 82, 1107-1112. http://dx.doi.org/10.1093/jnci/82.13.1107

[20] Tacar, O., Sriamornsak, P. and Dass, C.R. (2013) Doxorubicin: An Update on Anticancer Molecular Action, Toxicity and Novel Drug Delivery Systems. Journal of Pharmacy and Pharmacology, 65, 157-170. http://dx.doi.org/10.1111/j.2042-7158.2012.01567.x 
Submit or recommend next manuscript to OALib Journal and we will provide best service for you:

- Publication frequency: Monthly

- 9 subject areas of science, technology and medicine

- Fair and rigorous peer-review system

- Fast publication process

- Article promotion in various social networking sites (LinkedIn, Facebook, Twitter, etc.)

- Maximum dissemination of your research work

Submit Your Paper Online: Click Here to Submit

Contact Us: service@oalib.com 